\title{
LEVELS OF A COMPONENT CHARACTERISTIC OF AMYLOID SUBSTANCE IN SERA FROM NORMAL PERSONS AND PATIENTS WITH AMYLOIDOSIS
}

\author{
BY \\ THOS. J. MUCKLE \\ Department of Pathology, Royal Victoria Infirmary, University of Newcastle upon Tyne
}

In the course of immunological analyses of human amyloid substances, it was found that all sixteen specimens purified by a method involving ultrasonic disintegration, freeze-precipitation, and washing (Muckle, 1964), contained a component which was absent from similarly prepared normal tissues but was present in normal blood serum and plasma as an alpha-1 globulin (Muckle, 1967).

Similar results have been obtained by Cathcart, Comerford, and Cohen (1965), Dixon (1965), Milgrom, Kasukawa, and Calkins (1966), and Cathcart, Wollheim, and Cohen (1967a), using amyloid material purified by other techniques. Direct comparisons have not been made, but the descriptions suggest that the serum component characteristic of amyloid found in these investigations was the same substance.

In view of the possibility that amyloid deposition might result, at least in part, from imbalance of equilibrium between this component characteristic of amyloid (herein abbreviated to CCA) in the circulating blood and in connective tissue fluid, it seemed worthwhile to examine the serum levels in patients with amyloidosis.

\section{Material and Methods}

(1) Standard Barbitone Buffer.-Distilled water containing sodium diethyl barbiturate $\mathrm{M} 0.05$, barbituric acid $\mathrm{M} 0.01$, and sodium azide 0.05 per cent., $\mathrm{pH} 8.5 \pm$ $0 \cdot 1$.

(2) Extract of Purified Amyloid Fibrils.-Amyloid fibrils were isolated from amyloid bearing tissues and purified by Cohen's method (Cohen and Calkins, 1964), and a saturated extract was prepared by exposure to standard barbitone buffer at room temperature for 24 hours. This extract was found, by method 4 (vide infra), to contain approximately five times the normal serum level of CCA.

(3) Antiserum to $C C A$.-This was a rabbit antiserum (No. 220) raised against amyloid material purified by the method of Muckle (1964), and showed very strong activity against CCA. Traces of activity against IgG and $C^{\prime} 3$ complement did not interfere with reading of its immunodiffusion patterns (Fig. 1).

*Ionagar No. 2, Oxo, London.

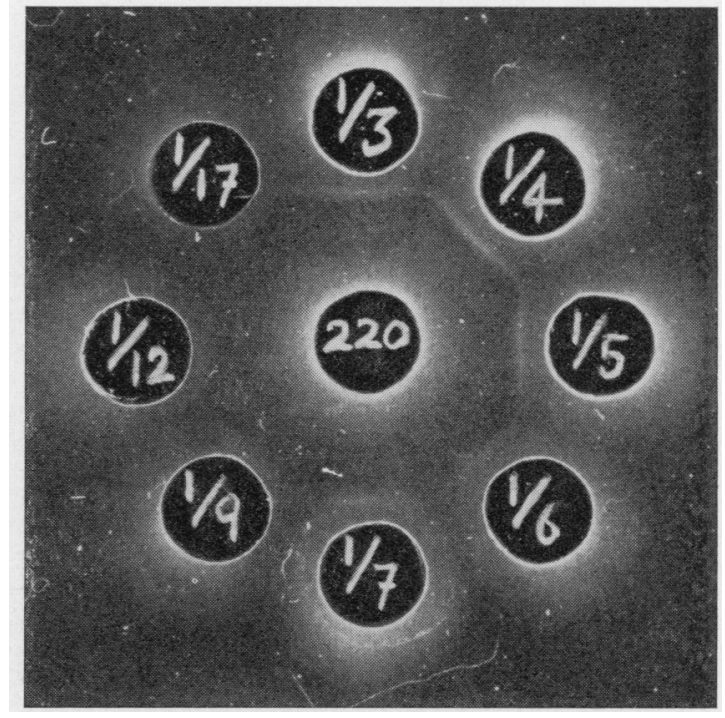

Fig. 1.-Double diffusion in agar gel. The central well contained antiamyloid antiserum 220 , while the peripheral wells contained the 210 pool normal standard reference serum at dilutions of, in a clockwise pool normal standard reference serum at dilutions of, in a clockwise
direction from 12 o'clock. $1 / 3,1 / 4,1 / 5,1 / 6,1 / 7,1 / 9,1 / 12$, and $1 / 17$. The weakest dilution of the standard normal reference serum which has produced a clear precipitin line with the antiserum is 1/7. Faint arcs for $C^{\prime} 3$ complement and immunoglobulin $G$, visible at up to $1 / 5$ or 1/6 dilutions, do not interfere with visualization of the arc for CCA since they are much nearer the antiserum well.

(4) Estimation of CCA Levels.-Serum CCA levels were assayed by comparing the precipitin end-points in agar gel double diffusion of serial dilutions of the test and standard sera against the antiserum. Standard barbitone buffered 0.8 per cent. agar gel* was used, precisely $3.75 \mathrm{ml}$. for each $3.9 \times 7.6 \mathrm{~cm}$. glass slide. A diffusion pattern of eight peripheral wells set at $0.35 \mathrm{~cm}$. distance from a single central well was used, and all wells were $0.30 \mathrm{~cm}$. diameter. The central well contained the antiserum and, since its end-point was at approximately 14 per cent. of normal standard serum CCA level, the peripheral wells contained aliquots of the test and standard sera at dilutions of $1 / 3,1 / 4,1 / 5,1 / 6,1 / 7,1 / 9$, $1 / 12$, and $1 / 17$. All sera were tested in duplicate, and a period of 16 hours' diffusion at room temperature provided optimum resolution. If, as occasionally happened, the duplicate readings differed from each other by one dilution, or if the titre was unusually high or low, the estimation was repeated at the same or appropriately altered serum dilutions. 
The standard reference serum was made up of a pool of sera from 210 healthy blood donors, and designated as 100 per cent. CCA level. The level in test sera was then expressed relative to this standard by the formula:

$$
\text { Test Level } \%=\frac{\text { titre of test serum }}{\text { titre of standard }} \times 100
$$

Aliquots of the standard pool serum, and all test sera, were stored at $-35^{\circ} \mathrm{C}$. until required. It was found that freezing somehow altered the CCA, perhaps causing polymerization since diffusion was slower and less distant from the well than when fresh serum was used. Prior warming of the frozen sera to $37^{\circ} \mathrm{C}$. for 30 minutes caused return to normal in this respect and was carried out for all estimations.

\section{Results}

(1) Confirmation of Specificity of Antiserum.-The standard serum was compared in double diffusion with the extract of purified amyloid fibrils against the antiserum. Confluence of the single precipitin line for the CCA in the extract with the major line for serum, without spurs or crossings, showed complete immunological identity (Fig. 2).

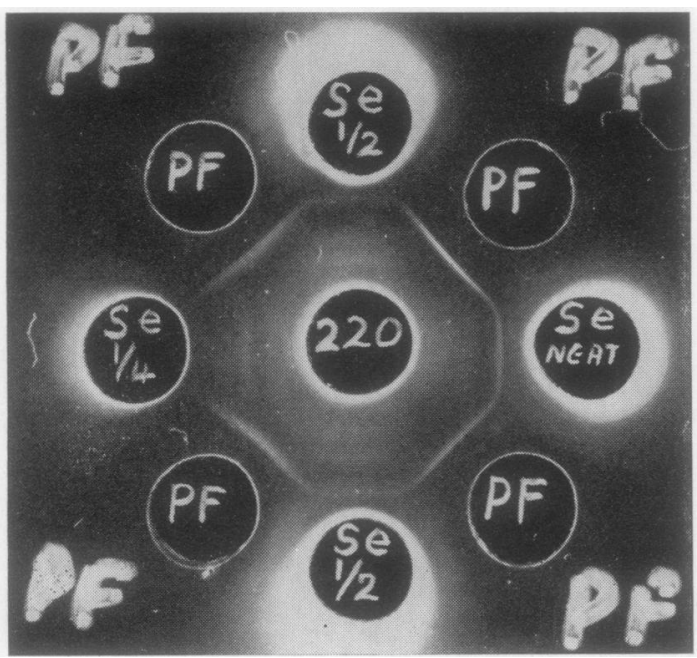

Fig. 2.-Double diffusion in agar gel. The central well contained antiserum 220. The four peripheral wells at $12,3,6$, and 9 o'clock contained normal human serum at dilutions of, respectively, $1 / 2$, neat, $1 / 2$, and $1 / 4$. The other peripheral wells contained extract of purified amyloid fibrils.

The single strong precipitin arc formed between antiamyloid antiserum 220 and the amyloid fibril extract shows complete immunological identity with the major arc for serum. Two other faint arcs developed with serum correspond to the minor activities of antiserur 220 , against immunoglobulin $G$ and $C^{\prime} 3$ complement; these are absent from the amyloid fibril extract.

(2) Reproducibility and Accuracy of the Method.The standard serum, one low level serum, and one high level serum were estimated blind sixteen times in comparison. The standard serum read clearly at $1 / 7$ on fourteen plates and, although still read as $1 / 7$, the other two patterns were a little less clear $\frac{5}{7}$ The low level serum read always at $1 / 3$, and the high level serum at barely $1 / 17$. Upon subsequents. estimations at a variety of different dilutions, the low level serum gave an average of 37 per cent? (range 36 to 43 ; similarly, the high level serum gave an average of 221 per cent. (range 214 to 257).

(3) Test Sera CCA Levels. -49 individual sera o $\frac{\vec{B}}{2}$ those which went to make up the 210-pool normats standard, and 28 amyloidotic sera were tested. The CCA levels in all the normal sera and in 25 of the amyloidotic sera, which included one primar $\vec{\omega}$ atypical, one myelomatous atypical, and 23 secon dary examples, showed a near normal type distri bution curve about a mean which was almost the same for both groups The levels in the 25 amyl $\stackrel{\infty}{-}$ oidotic sera, however, showed a highly significanto wider range than the normals (variance significan $\vec{B}$ at $\mathbf{P}=<0 \cdot 001$ ). The data for these sera are tabus lated against the normals in the Table, and given in histogram form in Fig. 3.

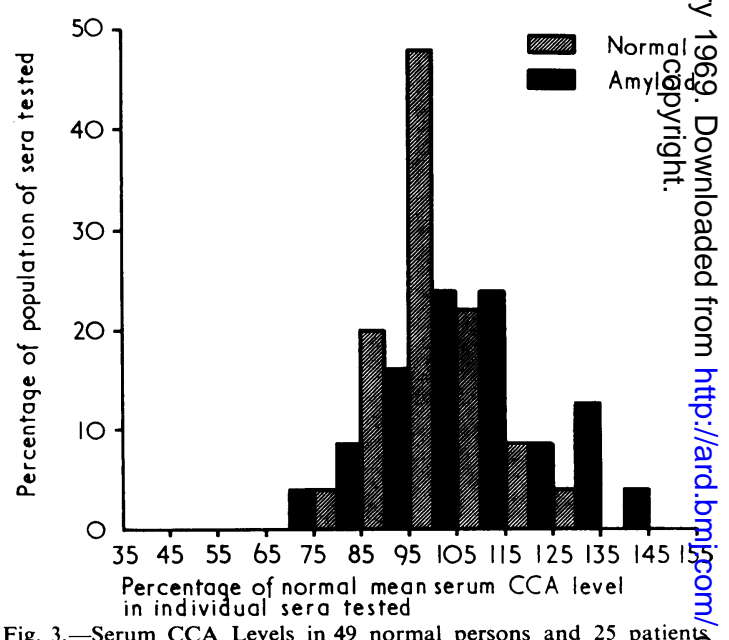

Fig. 3.-Serum CCA Levels in 49 normal persons and 25 patients with amyloidosis.

Three of the amyloidotic sera showed CCA leve widely divergent from the mean and range of theo others, and were not included in the statistical analysis for this reason. One showed a level o中 only 37 per cent.; this was from a patient whoseo Still's disease had been "burned out" 12 years before, and who died in uraemia with granulaa contracted amyloidotic kidneys. Two showed levers of 220 and 285 per cent., respectively: the first of these was from a patient with very early (as shown by rectal and renal biopsies) secondary amyloidos 
TABLE

COMPARISON OF SERUM CCA LEVELS IN NORMAL PERSONS AND PATIENTS WITH AMYLOIDOSIS

\begin{tabular}{|c|c|c|c|c|c|c|c|c|c|c|c|c|}
\hline \multicolumn{3}{|c|}{ Serum CCA Level-per cent. $\mathbf{N}$. } & \multirow{2}{*}{$\begin{array}{l}\cdots \\
\cdots \\
\cdots\end{array}$} & \multirow{2}{*}{$\begin{array}{c}65 / 75 \\
0 \\
0\end{array}$} & \multirow{2}{*}{$\begin{array}{r}75 / 85 \\
1 \\
2\end{array}$} & \multirow{2}{*}{$\begin{array}{r}85 / 95 \\
10 \\
20\end{array}$} & \multirow{2}{*}{$\begin{array}{r}95 / 105 \\
24 \\
48\end{array}$} & \multirow{2}{*}{ 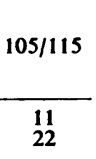 } & \multirow{2}{*}{$\begin{array}{c}115 / 1 ' 5 \\
4\end{array}$} & \multirow{2}{*}{$\begin{array}{r}125 / 135 \\
1 \\
2\end{array}$} & \multirow{2}{*}{$\begin{array}{c}135 / 145 \\
0 \\
0\end{array}$} & \multirow{2}{*}{$\begin{array}{c}\begin{array}{c}\text { Total } \\
\text { Sera } \\
\text { in } \\
\text { Group }\end{array} \\
49\end{array}$} \\
\hline Normal & $\begin{array}{l}\text { No. . } \\
\text { per cent.* }\end{array}$ & $\begin{array}{l}\cdots \\
\cdots\end{array}$ & & & & & & & & & & \\
\hline Amyloid & $\begin{array}{l}\text { No. ... } \\
\text { per cent. }\end{array}$ & $\begin{array}{l}\cdots \\
\cdots\end{array}$ & $\begin{array}{l}\cdots \\
\cdots\end{array}$ & $\begin{array}{l}1 \\
4\end{array}$ & $\begin{array}{l}2 \\
8\end{array}$ & $\begin{array}{r}4 \\
16\end{array}$ & $\begin{array}{r}6 \\
24\end{array}$ & $\begin{array}{r}6 \\
24\end{array}$ & $\begin{array}{l}2 \\
8\end{array}$ & $\begin{array}{r}3 \\
12\end{array}$ & $\begin{array}{l}1 \\
4\end{array}$ & 25 \\
\hline
\end{tabular}

The variance ratio test shows that $F=5.5$ approx., which is highly significant $(P<0.001)$.

*The normal group level percentages are to the nearest whole number.

accompanying early but actively progressive idiopathic interstitial pulmonary fibrosis; the second was from a patient in terminal uraemia from idiopathic nephropathic amyloidosis of typical distribution.

\section{Discussion}

This method of protein estimation gave an accuracy of little better than \pm 20 per cent., but the study was made only as a preliminary attempt to determine whether serum CCA levels in amyloidosis showed any departures from normal which might be worth further investigation. Since the results seem to show that this is the case, it is intended to extend the investigation to serial estimations in amyloidosis in humans, in experimental amyloidosis, and in a variety of other human diseases. The radial diffusion technique will be used for this, since it is capable of providing an accuracy in the region of \pm 2 per cent. (Mancini, Carbonara, and Heremans, 1965).

It is not yet known whether formation of amyloid deposits may be related to abnormal catabolism or anabolism of CCA in connective tissue, or to local tissue conditions which favour its sequestration at the expense of that circulating in the blood. The significance of the abnormal levels found in some of these patients with amyloidosis therefore cannot be stated with certainty, but some observations may be considered relevant.

The 25 patients whose serum levels were statistically analysed had in common substantial proteinuria and established but, as far as can be judged, probably only slowly progressive amyloidosis. Their greater than normal range of serum CCA levels may have been related to low grade and variable activity of their amyloidosis, or modification of plasma volume and protein concentration due to proteinuria or other haemodynamic factors. Whatever the cause, the present findings correspond closely to those of Cathcart, Wollheim, and Cohen (1967b), and support their conclusion that isolated estimations of serum CCA levels are unlikely to be generally useful in diagnosis of the presence of amyloidosis.

However, the three cases with very abnormal levels are worthy of special consideration. A very low level found in the post mortem serum specimen may have been due to cold precipitation of the CCA during refrigeration of the body, and the high level found in the serum of a patient in terminal uraemia may have been the consequence of increased solubility of the CCA due to alteration of blood pH or some other physico-chemical factor. On the other hand, the levels in these two cases correlated with the apparent degree of activity of their amyloid disease, and this association seems to be suppristed by the high level present in the serum of a nor uraemic patient with only minimal proteinuria ind no other evident renal embarrassment but eariy and almost certainly actively progressive amyloidosis accompanying idiopathic interstitial pulmonary fibrosis. These results suggest that, while the serum CCA level does not apparently reflect either the presence or the amount of amyloid deposition in the body, it may prove to be of some clinical value in assessing therapy and prognosis by providing an indication of the progressive activity of the amyloidogenic process.

Such an association, if real, would also facilitate exploration of the pathogenesis of amyloidosis, but its evaluation will require investigation of serum CCA levels in experimental amyloidosis; in conditions involving alterations of plasma volume; in non-amyloidotic proteinuria; in non-amyloidotic patients with diseases which predispose to amyloidosis; in all forms of amyloidosis at various stages of their progress; and in many other diseases. Eventually it may prove possible to carry out balance studies and trace metabolically specifically labelled CCA in experimental amyloidosis, and even in the human disease. 


\section{Summary}

Serum levels of a component characteristic of amyloid substance in 49 normal persons and 28 patients with amyloidosis were estimated by a double diffusion precipitin technique in agar gel. Levels in amyloidotic patients showed a highly significantly wider range than those in normal subjects, and there was some indication that raised levels might be associated with actively progressive amyloidosis.

I am indebted to my many colleagues who provided normal sera, and clinical data and serum samples from their patients; to Mrs. E. Beattie for technical assistance; and to the Arthritis and Rheumatism Council for Research in Great Britain for grant No. 18228 which in part supported this work.

\section{REFERENCES}

Cathcart, E. S., Comerford, F. R., and Cohen, A. S. (1965). New Engl. J. Med., 273, 143 (Immunologic studies on a protein extracted from human secondary amyloid).

_- Wollheim, F. A., and Cohen, A. S. (1967a). J. Immunol., 99, 376 (Plasma protein constituents of amyloid fibrils).

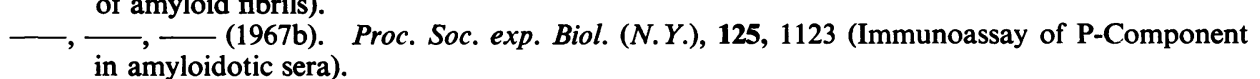

Cohen, A. S., and Calkins, E. (1964). J. Cell Biol., 21, 481 (The isolation of amyloid fibrils and a study of the effect of collagenase and hyaluronidase).

Dixon, F. J. (1965). In discussion in "Immunopathology-IV. International Symposium", ed. P. Grabar and P. A. Miescher, p. 309. Schwabe, Stuttgart.

Mancini, G., Carbonara, A. O., and Heremans, J. F. (1965). Immunochemistry, 2, 235 (Immunochemical quantitation of antigens by single radial immunodiffusion).

Milgrom, F., Kasukawa, R., and Calkins, E. (1966). J. Immunol., 96, 245 (Studies on antigenic composition of amyloid).

Muckle, T. J. (1964). Nature (Lond.), 203, 773 (Protein components of amyloid).

(1967). Thesis, University of Newcastle upon Tyne (Plasma proteins in amyloid substance).

Les taux sériques d'une partie composante caractéristique d'une substance amyloide chez des sujets sains et des malades atteints d'amyloidose

\section{RÉSUMÉ}

Les taux sériques d'une partie composante caractéristique d'une substance amyloïde chez 49 sujets sains et chez 28 malades atteints d'amyloïdose ont été estimés par la technique de double diffusion de la précipitine en gélose. Les taux chez les malades atteints d'amyloìdose ont montré une plus grande variation d'une très haute signification que ceux chez les sujets sains, et il y avait quelque indication que les taux élevés pourraient être associés à une amyloỉdose progressive et active.
Niveles séricos de un componente caracteristico de unp substancia amiloidea en personas normales y pacientes con? amilosis

\section{SUMARIO}

Los niveles séricos de un componente característico de una substancia amiloidea en 49 personas normales y 28 pacientes con amilosis fueron calculados mediante una técnica de doble difusión de precipitina en gel agárica. Los niveles en pacientes amiloidóticos mostraron variaciones significativamente más amplias que en sujetos sanos, y hubo cierto indicio de que los niveles elevados quizá estuviesen vinculados a una amilosis progresiva y activa. 